\title{
Assessment of Effectiveness of Institutional Forms of Regional Innovative Infrastructure
}

\author{
Zenchenko S.V.* \\ Institute of economics and management \\ North Caucasus Federal University \\ Stavropol, Russia \\ e-mail: zen_sveta@mail.ru
}

\section{Zaitsev A.G.}

Institute of economics and management

Oryol State University named after I.S. Turgeneva

Oryol, Russia

e-mail: cbap@bk.ru

\author{
Maltsev A.A. \\ Faculty of Economics and Management \\ Southwestern State University \\ Kursk, Russia \\ e-mail: maltsev@transoper.ru
}

\section{Mashegov P.N.}

Institute of economics and management Oryol State University named after I.S. Turgeneva Oryol, Russia

e-mail: yand-man@yandex.ru

\author{
Radyukova Ya.Yu. \\ Institute of economics, management and service \\ Tambov State University named after G.R. Derzhavina \\ Tambov, Russia \\ e-mail: radyukova68@mail.ru
}

\begin{abstract}
The article considers the problem of the system formation for assessing the effectiveness of the operation of innovation infrastructure facilities, in particular, and various institutional forms of regional innovation infrastructure, in general. The research includes a comparative analysis of various institutional forms of regional innovation infrastructure. Statistical data on infrastructure facilities related to various institutional forms are considered. There is the positive dynamics in the development of innovation infrastructure shown both in the context of individual institutional forms and in terms of individual regions in the paper, also is noted the presence of institutional effects in the development of innovative infrastructure. This is confirmed by the analysis of the geographical distribution of various objects of innovation infrastructure in the Central and Siberian federal districts, which is recorded as uneven and cannot be explained only by factors of the level of regional innovative potential. The existence of the "life cycle" institutional effect is noted, which is confirmed by an analysis of the dynamics of the quantitative characteristics of economic agents related to various institutional forms. A methodology for the formation of a system for assessing the effectiveness of institutional forms of regional innovation infrastructure is proposed, a characteristic feature of which is the relationship between the indicators used and the life cycle stage, which allows comparing the effectiveness of government spending on maintaining the functioning of innovation infrastructure, both within the framework of entities of the same type and between individual institutional forms.
\end{abstract}

Keywords — institutions, innovations, infrastructure, region.

\section{INTRODUCTION}

As with economic agents in general, the effectiveness of infrastructure should be evaluated through a comparison of costs and revenues. However, in relation to infrastructure, such a comparison should be carried out in two coordinates:

1. Through the cost ratio of economic agents with access to infrastructure, and not having such an opportunity. The greater the possibility of reducing production and transaction costs for those economic agents that use the infrastructure, the higher its attractiveness and operational efficiency.

2. Since the economic agents that have taken advantage of the infrastructure reduce their costs, it is assumed that either by expanding the scope of activities or by entering new highyield markets, they will, in the long run, compensate for the costs of the state.

This implies, as a matter of fact, the costs in the form of investments in facilities under construction and the current costs of maintaining the functioning of infrastructure facilities, as well as the "lost profit" of the state in the form of "lost revenue" of budgets of various levels that arises from the provision of various preferences (tax benefits) to economic agents who act as residents of infrastructure projects. This is precisely the logic of most recommendations for assessing the effectiveness of infrastructure. [1].

This approach, which is complicated from the point of view of data collection, however, is transparent for "technical" systems (for example, transport infrastructure reduces the cost of moving the subject of labor between repartitions). The "technical" infrastructure affects the rules of agent behavior 
indirectly, the manifestation of opportunistic behavior when using it is difficult. A completely different picture develops when the rules of the game on the market change due to soft loans or taxation for agents with certain formalized characteristics. In this case, the regional innovation infrastructure, in general, and its individual objects, in particular, should also be considered as "sets of rules", that is, an institution or an institutional form. This approach is also found in the scientific literature [2], but, much less frequently. In this case, it becomes necessary to take into account institutional effects. For example, "Critics of Lucas", [3] which claims that it is impossible to predict the consequences of changes in economic policy based on historical data without taking into account changes in the behavior of market agents under the new rules (new institutions). For innovative infrastructure, this is of particular importance, since there is always a fork of goals between the goals of economic agents (infrastructure users) and the state (the creator of infrastructure facilities and the corrector of institutional forms). The economic agent seeks to reduce costs, and the state ensures the development of priority activities. Moreover, formal rules are used to identify economic agents, which means that it becomes possible to formally comply with the rules, demonstrating, in fact, an opportunistic strategy of behavior.

There are a large number of institutional forms of regional innovation infrastructure. It is proposed to limit the most common of them. Small Innovative Enterprises (MIPs) are legal entities created within the framework of the Federal Law No. 217 of August 2, 2009. [4]. The parameters of their activities are monitored by a special monitoring body [5]. Techno park is "a complex of communal, transport and technological infrastructure facilities managed by the management company that provides a full cycle of services for the placement and development of innovative companies that are residents of the techno park". [6]. Techno parks, apparently, have the longest history among institutional forms of regional infrastructure [7]. Industrial park: "A complex of real estate objects ran by a specialized management company, consisting of a land plot (plots) with industrial, administrative, warehouse and other buildings, structures and structures, provided with the engineering and transport infrastructure necessary to create a new industrial production, as well as having the necessary legal regime for the implementation of production activities [8]. Special economic zones that appeared after the adoption of the Federal Law of July 22, 2005 No. 116-FZ "On Special Economic Zones in the Russian Federation" in 2006 [9]

Thus, a twofold task arises: firstly, to analyze the effectiveness of various institutional forms of regional innovation infrastructure and, secondly, to formulate assessment approaches that take into account the presence of institutional effects.

\section{METHODS AND MATERIALS}

A comparative analysis of various institutional forms of regional innovation infrastructure is carried out in the work. Statistical data on infrastructure facilities related to various institutional forms are considered.

\section{RESULTS AND DISCUSSION}

According to the Techno parks of Russia Association, the total revenue of residents of techno parks in 2017 amounted to 270.3 billion rubles. At the same time, the volume of products that can be identified as import-substituting amounted to 35.9 billion rubles or more than $12 \%$ of gross revenue. The number of intellectual property registered by residents of technology parks amounted to 1,172 units, and the average amount of expenditures of one resident on $\mathrm{R} \& \mathrm{D}$ during the year is 2.7 million rubles. There has been a steady increase in the number of technology parks in Russia, on average, about $25 \%$ of the number of existing in the year. The number of regions in which techno parks operate has significantly increased (from 30 in 2014 to 54 in 2018). The total area of technology parks is steadily increasing. The change in the average area of the techno park (with the maximum value in 2016) allows judging that the techno parks created in recent years were significantly smaller than those that were created before 2016. The dynamics of the intensity of the functioning of techno parks in Russia shows a positive trend. The level of area occupation will steadily increase, as will the area of commissioned premises. The more then $70 \%$ area utilization indicates both the sufficient number of existing residents and the presence of some potential to attract new ones. The growth in the number of residents is proportional to the number of technology parks being formed, however, the average number of residents in one technology park varies considerably from year to year from 35 to 60 units. At the same time, the share of small and medium-sized businesses steadily exceeds $70 \%$.

According to 2018, industrial parks attracted 1.2 trillion rubles of direct investments in the creation of new industries, and 2882 enterprises are located on the territory of industrial parks. The number of industrial parks for the year increased by 61 units (more than $30 \%$ ). Innovation infrastructure facilities identified as industrial parks are located in 60 regions. At the same time, it should be borne in mind that out of 227 platforms, only 150 have operational status. Other industrial parks are in the process of formation, demonstrating the potential of this form of innovative infrastructure. Experts estimate state participation in financing the creation of industrial parks as exceeding half. The difficulty of an accurate assessment is due to the presence of various channels of state financing of residents (various targeted programs, grants, etc.), which cannot always be monitored by the management company. However, the number of management companies that belong to the category of private, industrial parks of this type is almost double that of state-owned ones The effectiveness of industrial parks is also indicated by the fact that one ruble invested in their creation (that is, in the formation of infrastructure) accounts for eight rubles of direct investment in production assets. A positive trend can also be considered an increase in facilities of the greenfield type, that is, created in a clean field, which indicates that investors have a "risk appetite" and are willing to make long-term investments. At the same time, the number of objects of the "brownfield" type is also steadily growing, which is associated with the processes of reindustrialization and the inclusion in the economic turnover of sites that already have the basic elements of the technical infrastructure. [11] 
At the end of 2018, there were 44 industrial clusters located in 33 regions of Russia, which brought together 620 residents involved in 24 supported projects. The total investment volume of the supported projects amounted to 21,792.2 million rubles. of which 15877.3 million rubles are private, the increase in the number of jobs amounted to 3197 units, and the expected budgetary effect is the increase 2.2 rubles in tax revenues to the federal budget per ruble of subsidy. [12]

The dynamics of the functioning indicators of special economic zones shows that out of 28 SEZs: 11 - industrial type, 6 - technological-innovative type, 11 - touristrecreational, and 1 - port. All indicators of the SEZ functioning show positive dynamics. This applies to both domestic and foreign residents; both quantitative indicators (revenue) and qualitative indicators (labor productivity, which, on average, is one and a half times higher than the all-Russian one). The deterioration of the economic and political situation in 2015 led to a "sagging" growth rate of investments, however, in the future, growth recovered. The structure of direct investments by sources of financing in 2018 amounted to: $91.5 \%$ - off-budget investments by residents of special economic zones (59920 million rubles); $3.2 \%$ - funds from the federal budget (2091 million rubles); $5.5 \%$ - funds from regional budgets (3606 million rubles). For the vast majority of SEZs, the amount of benefits provided from budgets of various levels is many times exceeded by additional tax revenues generated as a result of the activities of SEZs. [13]

Special economic zones are one of the longest-running institutional forms of innovation infrastructure. There are detailed statistics and analytical reports generated by various expert groups for the SEZ. It is of interest to compare their results with each other. Consider the analytical reports generated by: the Association for the Development of Clusters and Technology Parks of Russia, the Ministry of Economic Development of the Russian Federation and the Audit Chamber of the Russian Federation.

The Ministry of Economic Development evaluates the effectiveness of the functioning of the SEZ by nineteen absolute and relative quantitative indicators, as well as four calculated performance indicators: "an efficiency indicator reflecting the performance of residents; an efficiency indicator reflecting the profitability of investing in the federal budget, budgets of the constituent entities of the Russian Federation and local budgets in the creation of engineering, transport, social, innovative and other infrastructure; performance indicator reflecting the activities of governing bodies and a consolidated performance indicator. "Analyzing the effectiveness rating of special economic zones according to these indicators, we can state that. Despite some differences in the values of the indicators between the reports of the Association for the Development of Clusters and Techno parks and the Ministry of Economic Development, they are unanimous regarding the overall effectiveness of this institutional form. [14] Fundamentally different estimates and conclusions are presented in the report of the Accounts Chamber of the Russian Federation, [15] which notes numerous facts of irrational asset management and concludes that for more than a decade more significant, special economic zones have not been able to provide a solution the tasks assigned to them. In particular, they never became drivers of the regional development in which they functioned.

The presence of institutional effects in the development of innovative infrastructure is confirmed by the following analysis of geographical distribution. The number of various innovation infrastructure facilities in the Central and Siberian Federal Districts. There are very significant differences between regions recorded both in the composition and number of infrastructure facilities. These macro regions cover almost half of each type of object, so the sample can be considered representative. As a result of the analysis, no relationship was found between the development of different types of infrastructure within one region, or between the economic potential of the region and its innovative infrastructure (provided that the Moscow region is excluded as atypical for the sample). Given that a significant part of the regions has low innovative potential, and the infrastructure in them is represented by single objects, such a comparison does not seem to be quite correct. To confirm the thesis that the availability of innovative infrastructure facilities is largely determined not by the level of development of the region, but by the historically established formal and informal institutions in it, we will consider regions with the best infrastructure development separately. There is about $30 \%$ of infrastructure facilities concentrate in only seven regions. However, among these regions, the objects of innovation infrastructure are distributed extremely unevenly both within the framework of a separate category and in the ratio "small innovative enterprises - technology parks - clusters". The analysis allows concluding that imbalances appear among all groups of regions, which confirms the previously put forward hypothesis about the institutional conditionality of the choice of the type of infrastructure facilities. [16]

The presence of the "life cycle" institutional effect is confirmed by an analysis of the dynamics of the quantitative characteristics of the economic entities representation belonging to various institutions of regional innovation infrastructure. [17] A common characteristic of the different institutions' dynamics of regional innovation infrastructure is the presence of the following phases.

1. "Curiosity" the number of objects of this type of infrastructure increases significantly over a short period of time (before that the institute did not exist or had significant differences). This stage is characterized by overestimated expectations of agents regarding the gains that the institute brings and a poor understanding of the specifics of its functioning.

2. "Saturation." At this stage, the number of objects is stabilized. Changes in numbers are largely due to changes in market conditions.

3. "Aging". Agents lose interest in this institution. The amount of costs incurred by the institution (for example, a certain geographical location) becomes disproportionate to the benefits received (for example, the termination of the state support program).

4. "Renovation". Institute change. Significant enough for the agents to respond to it as the "Curiosity" stage. 
In the framework of this work, we propose not a set of specific indicators for assessing the effectiveness of institutional forms of regional innovation infrastructure, but the general architecture of their application depending on the stage of the institute's life cycle. As a methodology for calculating specific indicators, standard methods can be used. For example, recommendations of the Ministry of Communications. [18] The types of indicators used are distributed in accordance with the phases of the life cycle of the institute as follows:

Curiosity. Assessment of the state of infrastructure facilities by qualitative and quantitative criteria, rating estimates (the number of jobs created, planned indicators of economic efficiency, the presence of specific elements of equipment, laboratories, etc.)

Saturation. Relative (rating) assessment of the state of infrastructure facilities by qualitative and quantitative indicators. Assessment of the commercial effectiveness of the project (achieving self-sufficiency, the number and proportion of participants with private capital, etc.).

Aging. Relative (rating) assessment of the commercial effectiveness of the project (achieving self-sufficiency, the number and proportion of participants with private capital, etc.). Comparison of the effectiveness of various institutions, a retrospective assessment of the impact on the development of territories and industries, including the type "if it weren't".

Renovation. Comparison of the effectiveness of the same institutions for different territories and industries, including the type "if it weren't" and the attempt to financially evaluate the totality of effects associated with the functioning of the institute (taking into account the losses and benefits of providing preferences).

\section{CONCLUSION}

The analysis of the innovation infrastructure development in Russia allowed identifying general patterns that are characteristic of various institutional forms, in particular, there is a periodicity in the intensity of their use, which corresponds to the dynamics of the life cycle of economic systems.

A technique is proposed for the formation of a system for assessing the effectiveness of institutional forms of regional innovation infrastructure, a characteristic feature of which is the relationship between the indicators used and the life cycle stage, which allows comparing the effectiveness of government spending on maintaining the functioning of innovation infrastructure, both within the framework of entities of the same type and between individual institutional forms.

\section{References}

[1] E. Sibirskaya, L. Oveshnikova, O. Stroeva, "Methodology for assessing the effectiveness of infrastructure support for entrepreneurship", GISAP Econ., Jurisprud. and Manag., no. 6, 2015. Retrieved from: http://journals.gisap.eu/index .php / EcoJuris / article / download / $865 / 831$

[2] L.V. Obolenskaya, "Innovation infrastructure as a comprehensive development institution", Econ., Taxes, Law, no. 2, pp. 14-20, 2015. Retrieved from: http://cyberleninka.ru/article/n/innovatsionnayainfrastruktura-kak-kompleksnyy-institut-razvitiya.pdf

[3] R. Lucas, Econometric Policy Evaluation: A Critique [Carnegie Rochester Conf. Ser. on Public Policy, no. I, 1976].

[4] Federal Law no. 217, 2009, Federal Law of the Russian Federation of 2 August 2009, no. 217-Ф3 "On Amending Certain Legislative Acts of the Russian Federation on the Establishment of Business Societies by Budget Scientific and Educational Institutions for Practical Application (Implementation)" results of intellectual activity". SPA" Consultant Plus".

[5] FSBI NII RINKCE, 2016. Retrieved from: https://mip.extech.ru/ index.php

[6] Technoparks, 2015, GOST R 56425 - 2015 Approved and enforced by Order of the Federal Agency for Technical Regulation and Metrology of 10 June 2015, no. 614-st. Moscow: Standartinform, 2015.

[7] N. Ekimova, Russian Development Institutes: a retrospective of formation, 2016. Retrieved from: http://kapital-rus.ru/articles/article/ instituty_razvitiya_rossii_retrospektiva_formirovaniya/

[8] Industrial parks, Requirements, 2015, GOST R 56301-2014, Approved and enforced by Order of the Federal Agency for Technical Regulation and Metrology of 12 December 2014, no. 1982-Art. Moscow: Standartinform, 2015

[9] D.G. Sandler, P.D. Kuznetsov, "Industrial parks in Russia: conceptual elaboration of projects", Reg. Econ., no. 1, pp. 76-88, 2015.

[10] L.V. Danilov, E.A. Kashinova, E.I. Kravchenko, M.M. Bukharova, M.A. Labudine, Fifth annual review of "Technoparks of Russia - 2019", In: Association for the Development of Clusters and Technology Parks of Russia. Moscow: AKIT RF, 2019, 110 p.

[11] Review of industrial parks of Russia - 2019, In: Association of Industrial Parks of Russia, 2019, 114 p.

[12] Features of the functioning and State support of industrial clusters, In Association of clusters and technology parks of Russia. Retrieved from: http://akitrf.ru/upload/medialibrary/dbe/dbedad4933f4 23a224145ce6b984e0a1.pdf

[13] I.V. Golubkin, M.M. Bukharova, L.V. Danilov et al., Business navigator for special economic zones of Russia - 2019, In: Association for the Development of Clusters and Technology Parks of Russia. Moscow: AKIT RF, 2019, 183 p.

[14] Report on the results of the functioning of special economic zones for 2018 and for the period from the beginning of the functioning of special economic zones. Retrieved from: https://www.economy.gov.ru/ material/file/ 6548510844d75e1246b52f435ebf0499 / report2018.pdf

[15] Report on the results of the control event "Audit of the effectiveness of the use of public funds aimed at the creation and development of special economic zones", Decision of the Board of the Accounts Chamber of the Russian Federation of 11 December 2013, no. 47K (938)

[16] I. Lyapina, P. Mashegov, E. Petrukhina, O. Stroeva, A. Maltsev, "Institutional effects in development of regional innovational infrastructure", Int. J. of Trade and Global Markets, vol. 12, no.1, pp. 26-42, 2019.

[17] T.S. Kolmykova, A.A. Maltsev, "Institutional effects and the functioning efficiency of innovation infrastructure facilities", Reg.: syst. econ., manag., vol. 4, no. 43, pp. 24-32, 2018.

[18] Methodology of the Ministry of Communications and Mass Media, 2010, Methodology for assessing the effectiveness of using federal budget funds allocated for the creation of techno-parks in the field of high technology. Retrieved from: http://minsvyaz.ru/uploaded/files/ Metodika_otsenki_ispolzovaniya_sredstv_federalnogo_budzheta.pdf 